\title{
Terpenoids and Aromatic Compounds from the New Zealand Liverworts Plagiochila, Schistochila, and Heteroscyphus Species
}

\author{
Fumihiro Nagashima, ${ }^{*}$ Takashi Sekiguchi, Shigeru Takaoka, and Yoshinori Asakawa \\ Faculty of Pharmaceutical Sciences, Tokushima Bunri University; Yamashiro-cho, Tokushima 770-8514, Japan. \\ Received December 1, 2003; accepted January 19, 2004
}

\begin{abstract}
A new clerodane- and two new ent-rosane-type diterpenoids have been isolated from the New Zealand liverworts Heteroscyphus billardierii and Plagiochila deltoidea, respectively. The known bisbibenzyl compounds and acetophenones have also been isolated from Schistochila glaucescens and Plagiochila fasciculata. Their structures were established by extensive NMR techniques. Chemosystematics of the Plagiochila species have been discussed.
\end{abstract}

Key words Heteroscyphus billardierii; Plagiochila deltoidea; Plagiochila fasciculata; Schistochila glaucescens; ent-rosanetype diterpene; bisbibenzyl

A number of secondary metabolites possessing novel carbon skeletons have been isolated from liverworts, several of which show interesting biological activities. ${ }^{1,2)}$ The majority of these compounds are lipophilic terpenoids and phenolics. These compounds are also often valuable as chemosystematic and genetic markers. ${ }^{1,2}$ For the purpose of searching for novel compounds and their biological activity, we are currently studying the chemical constituents of New Zealand liverworts. ${ }^{3,4)}$ A number of endemic liverwort genera have been found in New Zealand, which are not related to those found in Japan. ${ }^{5}$

Four New Zealand liverworts, Heteroscyphus billardieri (Schwaegr.) Schniffn., Plagiochila deltoidea Lindenb., Plagiochila fasciculata LINDENB., and Schistochila glaucescens (Ноок.) STEPH., were further chemically analyzed to give three new diterpenoids: clerodane- (1) and ent-rosane-type $(\mathbf{2}, 3)$; three known terpenoids: ent-pimarane-type diterpenoid (4), lupane-type triterpenoid (5) and aromadendranetype sesquiterpenoid (6); and six known aromatic compounds: acetophenones $(\mathbf{7}, \mathbf{8})$ and bisbibenzyls $(9-\mathbf{1 2})$. Here, we report on the isolation and structural characterization of the new compounds and chemosystematics of two Plagiochila species.

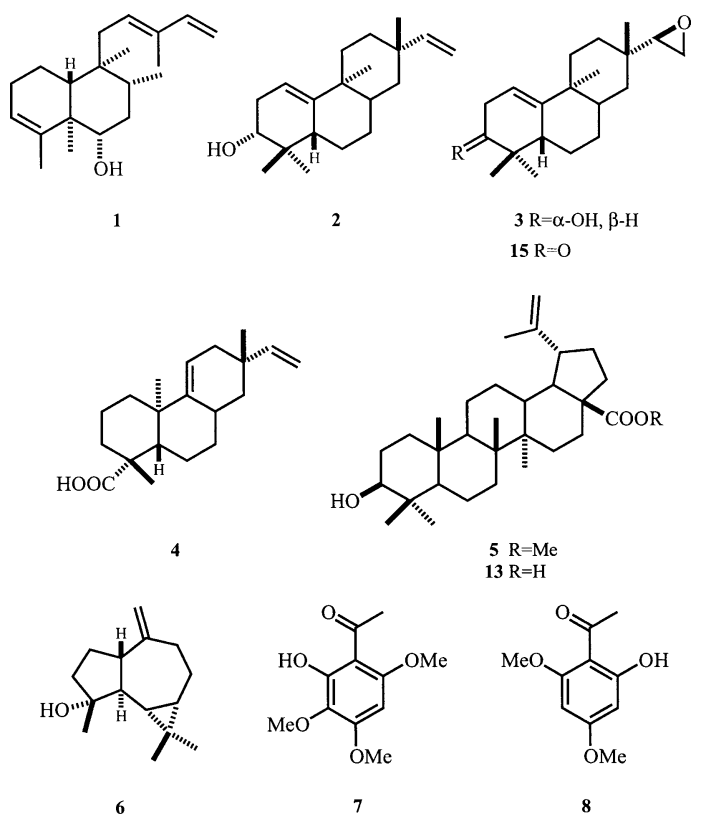

\section{Results and Discussion}

A combination of chromatography on silica gel, Sephadex LH-20 and preparative HPLC of the ether extract of $\mathrm{H}$. billardierii belonging to the Geocalycaceae resulted in the isolation of compound 1 .

The IR spectrum of compound $\mathbf{1}$ showed the presence of a hydroxy group $\left(3440 \mathrm{~cm}^{-1}\right)$, and its high-resolution electron impact mass spectrometry (HR-EI-MS) clarified the molecular formula as $\mathrm{C}_{20} \mathrm{H}_{32} \mathrm{O}$ (obs. $m / z 288.2455[\mathrm{M}]^{+}$). The ${ }^{1} \mathrm{H}-$ NMR spectrum (Table 1) showed the presence of three tertiary methyls, a secondary methyl, an oxygenated methine proton and a vinyl group. The ${ }^{13} \mathrm{C}-\mathrm{NMR}$ (Table 2 ) and its distortionless enhancement by polarization transfer (DEPT) spectra indicated the presence of two trisubstituted olefinic carbons $(\delta 122.5 \mathrm{~d}, 128.8 \mathrm{~d}, 135.2 \mathrm{~s}, 143.5 \mathrm{~s}$ ), vinyl carbons $(\delta 110.5 \mathrm{t}, 141.9 \mathrm{~d})$, a methine $(\delta 75.4)$ bearing a secondary hydroxy group, and also five methyls, four methylenes, two methines and two quaternary carbons, respectively. From the above spectral evidence, compound $\mathbf{1}$ was suggested to be a bicyclic diterpenoid. Successively, the analysis of ${ }^{1} \mathrm{H}-{ }^{1} \mathrm{H}$ correlated spectroscopy $\left({ }^{1} \mathrm{H}-{ }^{1} \mathrm{H}\right.$ COSY $)$, the heteronuclear multiple quantum coherence (HMQC) and the heteronuclear multiple bond correlation (HMBC) spectra of $\mathbf{1}$, as shown in

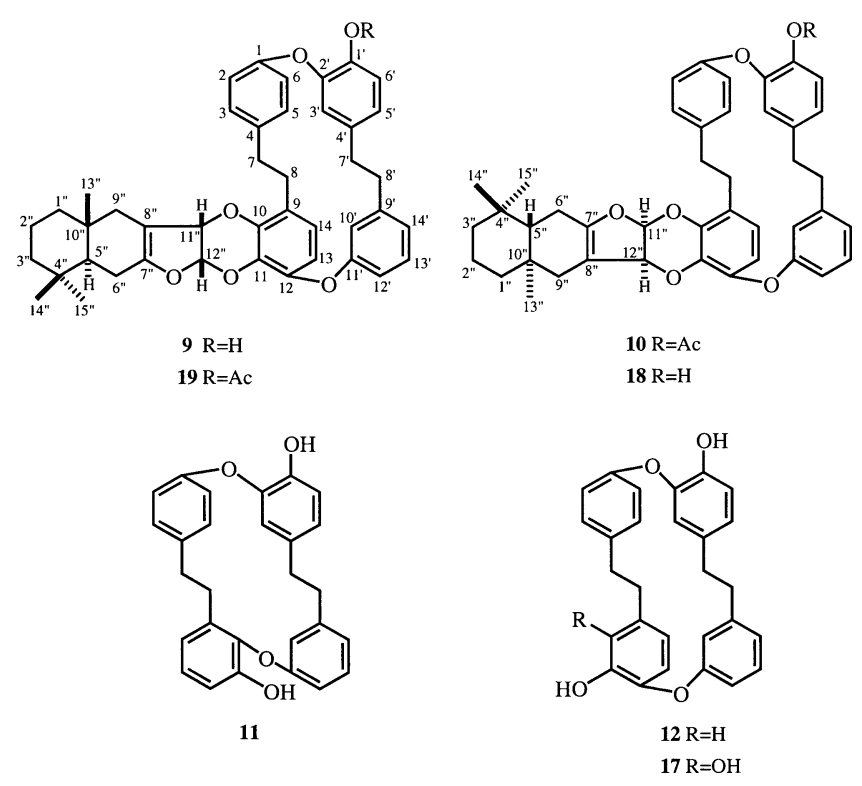


Table 1. ${ }^{1} \mathrm{H}-\mathrm{NMR}$ Spectral Data of $\mathbf{1}-\mathbf{3}\left(600 \mathrm{MHz}, \mathrm{CDCl}_{3}\right)$

\begin{tabular}{|c|c|c|c|}
\hline $\mathrm{H}$ & 1 & 2 & 3 \\
\hline 1 & $1.53-1.632 \mathrm{H}, \mathrm{m}$ & 5.39 quint. like (2.5) & 5.39 quint. like (2.2) \\
\hline \multirow[t]{2}{*}{2} & $2.02 \operatorname{brd}(17.9)^{a)}, \alpha$ & 1.92 dddd $(17.0,10.4,4.1,2.5), \alpha$ & 1.91 dddd $(17.0,10.4,4.1,2.2), \alpha$ \\
\hline & $1.89 \mathrm{~m}, \beta$ & $2.29 \operatorname{dddd}(17.0,5.8,5.8,2.5), \beta$ & $2.28 \operatorname{dddd}(17.0,5.8,5.8,2.2), \beta$ \\
\hline 3 & $5.22 \mathrm{brs}$ & $3.51 \mathrm{dd}(10.4,5.8)$ & $3.50 \mathrm{dd}(10.4,5.8)$ \\
\hline 5 & & $2.14 \mathrm{~d}$ sept. $(13.7,2.5)$ & $2.12 \mathrm{~d}$ sept. like $(14.0,2.2)$ \\
\hline \multirow[t]{2}{*}{6} & $3.53 \mathrm{dt}(10.2,4.9)$ & $1.35 \mathrm{~m}, \alpha$ & $1.34 \mathrm{~m}, \alpha$ \\
\hline & & $1.70 \mathrm{~m}, \beta$ & $1.66-1.73 \mathrm{~m}, \beta$ \\
\hline \multirow[t]{2}{*}{7} & $1.47 \mathrm{ddd}(13.5,13.5,11.3), \alpha$ & $1.23-1.28 \mathrm{~m}, \alpha$ & $1.22-1.28 \mathrm{~m}, \alpha$ \\
\hline & $1.53-1.63 \mathrm{~m}, \beta$ & $1.58 \mathrm{~m}, \beta$ & $1.59 \mathrm{~m}, \beta$ \\
\hline 8 & $1.53-1.63 \mathrm{~m}$ & $1.72 \mathrm{~m}$ & $1.66-1.73 \mathrm{~m}$ \\
\hline 10 & $1.30 \mathrm{dd}(11.8,2.2)$ & & \\
\hline \multirow[t]{2}{*}{11} & $2.14 \mathrm{dd}(15.7,8.0)$ & $1.67 \mathrm{~m}, \alpha$ & $1.66-1.73 \mathrm{~m}$ \\
\hline & 2.20 dd $(15.7,8.0)$ & 1.43 ddd $(13.7,13.7,3.6), \beta$ & $1.36-1.46 \mathrm{~m}$ \\
\hline \multirow[t]{2}{*}{12} & $5.42 \mathrm{t}(8.0)$ & $1.51 \mathrm{ddd}(13.7,13.7,3.6), \alpha$ & $1.36-1.46 \mathrm{~m}, \alpha$ \\
\hline & & $1.23-1.28 \mathrm{~m}, \beta$ & $1.13 \mathrm{~m}, \beta$ \\
\hline \multirow[t]{2}{*}{14} & $6.37 \mathrm{dd}(17.9,11.0)$ & $1.19 \mathrm{t}(13.5), \alpha$ & $1.22-1.28 \mathrm{~m}, \alpha$ \\
\hline & & $1.11 \mathrm{ddd}(13.5,3.8,2.7), \beta$ & $1.08 \mathrm{ddd}(13.2,3.6,2.5), \beta$ \\
\hline \multirow[t]{2}{*}{15} & $4.93 \mathrm{~d}(11.0)$ & $5.81 \mathrm{dd}(17.6,10.7)$ & $2.70 \mathrm{dd}(3.8,3.0)$ \\
\hline & $5.07 \mathrm{~d}(17.9)$ & & \\
\hline \multirow[t]{2}{*}{16} & $1.75 \mathrm{~s}$ & $4.85 \mathrm{dd}(10.7,1.6)$ & $2.62 \mathrm{dd}(4.9,3.8)$ \\
\hline & & $4.92 \mathrm{dd}(17.6,1.6)$ & $2.65 \mathrm{dd}(4.9,3.0)$ \\
\hline 17 & $0.86 \mathrm{~d}(6.3)$ & $0.98 \mathrm{~s}$ & $0.89 \mathrm{~s}$ \\
\hline 18 & $1.83 \mathrm{~s}$ & $1.02 \mathrm{~s}$ & $1.01 \mathrm{~s}$ \\
\hline 19 & $1.02 \mathrm{~s}$ & $0.67 \mathrm{~s}$ & $0.66 \mathrm{~s}$ \\
\hline 20 & $0.76 \mathrm{~s}$ & $0.91 \mathrm{~s}$ & $0.91 \mathrm{~s}$ \\
\hline
\end{tabular}

a) Coupling constants $(J$ in $\mathrm{Hz})$ are given in parentheses.

Table 2. ${ }^{13} \mathrm{C}$-NMR Spectral Data of $\mathbf{1}-\mathbf{3}$ and $\mathbf{1 5}$

\begin{tabular}{rrrrr}
\hline \hline $\mathrm{C}$ & $\mathbf{1}^{a)}$ & $\mathbf{2}^{b)}$ & $\mathbf{3}^{a)}$ & $\mathbf{1 5}^{b)}$ \\
\hline 1 & 18.2 & 115.2 & 115.4 & 115.0 \\
2 & 26.7 & 31.9 & 31.8 & 38.2 \\
3 & 122.5 & 75.1 & 75.0 & 214.5 \\
4 & 143.5 & 36.9 & 36.9 & 46.5 \\
5 & 44.0 & 43.6 & 43.6 & 44.5 \\
6 & 75.4 & 18.6 & 18.5 & 18.4 \\
7 & 37.9 & 25.7 & 25.7 & 25.3 \\
8 & 35.1 & 31.5 & 31.0 & 31.2 \\
9 & 40.1 & 37.0 & 37.1 & 37.3 \\
10 & 46.3 & 148.9 & 148.6 & 148.8 \\
11 & 36.7 & 35.3 & 34.7 & 34.4 \\
12 & 128.8 & 32.9 & 28.1 & 27.9 \\
13 & 135.2 & 36.4 & 33.3 & 33.4 \\
14 & 141.9 & 39.8 & 37.2 & 37.4 \\
15 & 110.5 & 151.3 & 61.0 & 61.0 \\
16 & 11.9 & 108.7 & 43.4 & 43.4 \\
17 & 16.0 & 22.3 & 19.4 & 19.2 \\
18 & 22.4 & 23.9 & 23.8 & 20.6 \\
19 & 14.8 & 12.9 & 12.8 & 19.4 \\
20 & 17.4 & 20.8 & 20.7 & 20.3 \\
& & & & \\
\hline
\end{tabular}

Measured in $\mathrm{CDCl}_{3}, a$ ) at $150 \mathrm{MHz}, b$ ) at $100 \mathrm{MHz}$.

Fig. 1, clarified that the structure of $\mathbf{1}$ could be a clerodanetype diterpenoid with a hydroxy group at C-6. Moreover, the phase sensitive nuclear Overhauser enhancement and exchange spectroscopy (NOESY) spectrum (Fig. 1) of $\mathbf{1}$ determined that the configuration of the hydroxy group at C-6 is $\alpha$. Thus, the structure of 1 was established as $6 \alpha$-hydroxy3,12E,14-clerodatriene.

Two new ent-rosane-type diterpenoids, $\mathbf{2}$ and $\mathbf{3}$, and the previously known diterpenoid acanthoic acid $(4)^{6)}$ were isolated from the ether extract of $P$. deltoidea. The known methyl ester (5) of betulinic acid (13) ${ }^{7}$ was also isolated
Table 3. ${ }^{13} \mathrm{C}$-NMR of Compounds $\mathbf{1 0}$ and $\mathbf{1 9}\left(150 \mathrm{MHz}, \mathrm{CDCl}_{3}\right)$

\begin{tabular}{rrr|rrr}
\hline \hline C & $\mathbf{1 0}$ & $\mathbf{1 9}$ & C & $\mathbf{1 0}$ & \multicolumn{1}{c}{$\mathbf{1 9}$} \\
\hline 1 & 153.4 & 153.1 & $10^{\prime}$ & 113.5 & 114.2 \\
2 & 120.2 & 120.7 & $11^{\prime}$ & 159.6 & 159.0 \\
3 & 130.1 & 130.1 & $12^{\prime}$ & 115.3 & 115.4 \\
4 & 137.3 & 137.1 & $13^{\prime}$ & 129.8 & 129.6 \\
5 & 130.1 & 130.1 & $14^{\prime}$ & 120.9 & 121.1 \\
6 & 120.2 & 120.7 & $1^{\prime \prime}$ & 40.8 & 41.5 \\
7 & 33.05 & 33.6 & $2^{\prime \prime}$ & 18.5 & 18.7 \\
8 & 30.7 & 29.5 & $3^{\prime \prime}$ & 41.9 & 42.1 \\
9 & 126.5 & 125.8 & $4^{\prime \prime}$ & 32.99 & 33.1 \\
10 & 143.6 & 144.7 & $5^{\prime \prime}$ & 48.9 & 48.8 \\
11 & 137.9 & 135.5 & $6^{\prime \prime}$ & 21.4 & 21.4 \\
12 & 142.4 & 142.4 & $7^{\prime \prime}$ & 156.1 & 156.5 \\
13 & 116.6 & 114.6 & $8^{\prime \prime}$ & 103.7 & 103.9 \\
14 & 123.4 & 123.4 & $9^{\prime \prime}$ & 40.0 & 41.1 \\
$1^{\prime}$ & 138.4 & 138.1 & $10^{\prime \prime}$ & 33.5 & 34.0 \\
$2^{\prime}$ & 150.8 & 150.8 & $11^{\prime \prime}$ & 82.0 & 81.0 \\
$3^{\prime}$ & 117.2 & 116.7 & $12^{\prime \prime}$ & 101.1 & 100.3 \\
$4^{\prime}$ & 141.4 & 141.5 & $13^{\prime \prime}$ & 19.3 & 19.5 \\
$5^{\prime}$ & 121.2 & 121.1 & $14^{\prime \prime}$ & 32.5 & 21.6 \\
$6^{\prime}$ & 122.9 & 122.8 & $15^{\prime \prime}$ & 21.6 & 32.7 \\
$7^{\prime}$ & 40.3 & 40.1 & OAc & 20.7 & 20.7 \\
$8^{\prime}$ & 41.8 & 40.6 & & 169.0 & 169.1 \\
$9^{\prime}$ & 143.5 & 143.9 & & & \\
& & & & & \\
\hline & & & &
\end{tabular}

from the methylated fraction with trimethylsilyldiazomethane. The structures of known compounds $\mathbf{4}$ and $\mathbf{5}$ were determined by comparison with their reference spectral data. ${ }^{6,7)}$

The IR spectrum of $\mathbf{2}$ confirmed the presence of a hydroxy group $\left(3390 \mathrm{~cm}^{-1}\right)$. The molecular formula was found to be $\mathrm{C}_{20} \mathrm{H}_{32} \mathrm{O}$ (obs. $\mathrm{m} / \mathrm{z} 288.2455$ ) by HR-EI-MS, indicating five degrees of unsaturation. The ${ }^{1} \mathrm{H}$ - and ${ }^{13} \mathrm{C}-\mathrm{NMR}$ spectra (Tables 1,2) of $\mathbf{2}$ showed the presence of a trisubstituted double bond $(\delta 115.2 \mathrm{~d}, 148.9 \mathrm{~s})$, a terminal vinyl group $(\delta 108.7 \mathrm{t}$, 

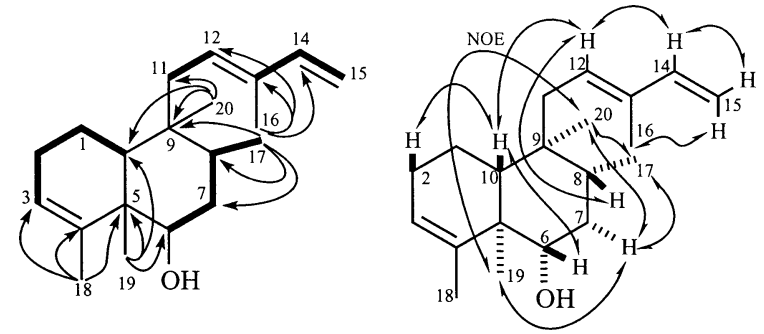

Fig. 1. The ${ }^{1} \mathrm{H}-{ }^{1} \mathrm{H}$ (Bold Lines), Long-Range ${ }^{1} \mathrm{H}-{ }^{13} \mathrm{C}$ (Arrows), and NOE Correlations (Half Arrows) of 1

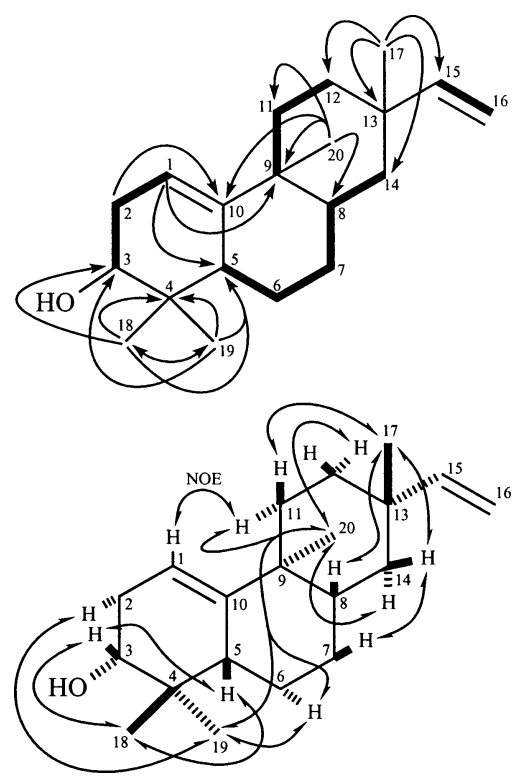

Fig. 2. The ${ }^{1} \mathrm{H}-{ }^{1} \mathrm{H}$ (Bold Lines), Long Range ${ }^{1} \mathrm{H}-{ }^{13} \mathrm{C}$ (Arrows), and NOE Correlations (Half Arrows) of 2

$151.3 \mathrm{~d})$ and an oxygenated methine ( $\delta 75.1)$, as well as four methyls, six methylenes, two methines and three quaternary carbons, respectively. These spectral data supported that compound 2 was a tricyclic diterpenoid. The ${ }^{1} \mathrm{H}-{ }^{1} \mathrm{H}$ COSY (Fig. 2) of 2 confirmed the presence of four partial structures: i) $-\mathrm{C}=\mathrm{CH}-\mathrm{CH}_{2}-\mathrm{CH}(\mathrm{OH})-$, ii) $-\mathrm{CH}-\mathrm{CH}_{2}-\mathrm{CH}_{2}-\mathrm{CH}-$ $\mathrm{CH}_{2}-$, iii) $-\mathrm{CH}_{2}-\mathrm{CH}_{2}-$, and iv) $-\mathrm{CH}=\mathrm{CH}_{2}$. The connectivity of each partial structure was clarified by the HMBC spectrum, as show in Fig. 2. Accordingly, the structure of $\mathbf{2}$ was supported to be a rosane-type diterpenoid with the hydroxy group at C-3. Its stereochemistry was determined by NOESY spectrum, as shown in Fig. 2. Thus, the stereostructure of 2 was clarified to be 1(10),15-rosadien-3 $\alpha$-ol. Furthermore, the absolute configuration of $\mathbf{2}$ was established as $(3 R)$-ent1(10),15-rosadien-3-ol by X-ray crystallographic analysis of the $m$-bromobenzoate derivative 14, as shown in Fig. 3.

The EI-MS spectrum of compound $\mathbf{3}$ showed a molecular ion peak at $\mathrm{m} / \mathrm{z} 304[\mathrm{M}]^{+}$, and its IR spectrum displayed the presence of a hydroxy $\left(3436 \mathrm{~cm}^{-1}\right)$ group. The ${ }^{1} \mathrm{H}$ - and ${ }^{13} \mathrm{C}$ NMR (Tables 1,2) were similar to those of compound 2 except for the absence of a terminal vinyl group. Therefore, its structure was suggested to be a rosane-type diterpenoid. The HR-EI-MS showed the molecular formula $\mathrm{C}_{20} \mathrm{H}_{32} \mathrm{O}_{2}$ (obs. $\mathrm{m} / \mathrm{z} 304.2404[\mathrm{M}]^{+}$), indicating five degrees of unsaturation. Oxidation of $\mathbf{3}$ gave a ketone $\mathbf{1 5}$ which showed only the presence of a carbonyl group $\left(1714 \mathrm{~cm}^{-1}\right)$ in the IR spectrum,

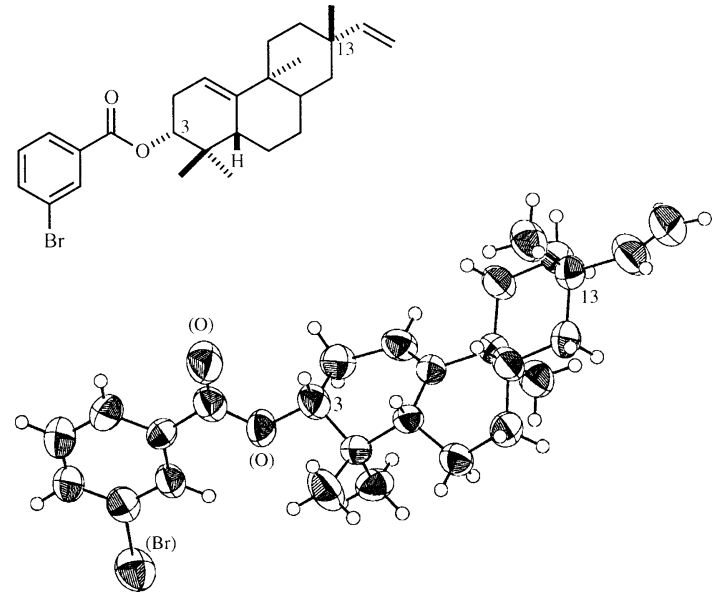

Fig. 3. The ORTEP Drawing of $\mathbf{1 4}$

Anisotropic ellipsoids are represented by a $50 \%$ probability level.

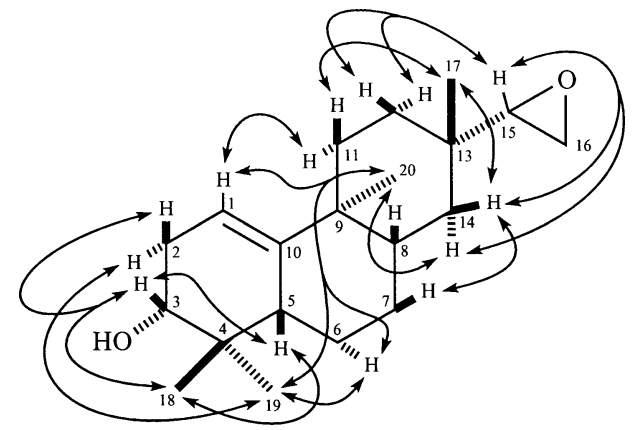

Fig. 4. The NOE Correlations of $\mathbf{3}$

suggesting compound $\mathbf{3}$ possessed a hydroxy and an epoxy group in the molecule. Furthermore, the structure of $\mathbf{3}$ was clarified to be 15,16-epoxy-1(10)-rosen-3-ol by detailed analysis of ${ }^{1} \mathrm{H}-{ }^{1} \mathrm{H}$ COSY, HMQC and HMBC spectra. The NOESY spectrum revealed the stereochemistry of $\mathbf{3}$ to be as shown in Fig. 4. In order to determine the absolute configuration, the esterification of compound 3 with $p$-bromobenzoyl chloride was carried out to give a $p$-bromobenzoate (16) with chlorine at C-16. The X-ray crystallographic analysis of $\mathbf{1 6}$ gave the ORTEP drawing shown in Fig. 5. Thus, the absolute configuration of 3 was established as $(3 R, 15 R)$-ent-15,16epoxy-1(10)-rosen-3-ol.

Three known compounds, ent-spathulenol (6), ${ }^{8)}$ 2-hydroxy-3,4,6-trimethoxy acetophenone (7) ${ }^{9)}$ and 2-hydroxy4,6-dimethoxy acetophenone $(\mathbf{8})^{10)}$ were isolated from the ether extract of $P$. fasciculata. The structures of these compounds were determined by comparison with an authentic sample or reference spectral data. Compounds $\mathbf{7}$ and $\mathbf{8}$ have already been isolated from $P$. fasciculata collected from different locations in New Zealand by Perry et al. ${ }^{11)}$

Previously we reported the isolation of novel macrocyclic bisbibenzyls neomarchantins A (12) and B (17), and marchantin C (11) from S. glaucescens. ${ }^{12)}$ Further fractionation of the ether extract of $S$. glaucescens collected from various locations resulted in the isolation of two sesquiterpenebisbibenzyl compounds 9 and 18, together with two known bisbibenzyls, marchantin $\mathrm{C}(\mathbf{1 1})^{13)}$ and neomarchantin A (12) ${ }^{12)}$ and stigmasterol. The determination of compounds 11 and 12 were confirmed by comparison with ${ }^{1} \mathrm{H}$ - and ${ }^{13} \mathrm{C}$ - 
<smiles>CC12CC[C@@](C)([C@H](O)CCl)CC1CC[C@@]1(C)C2=CC[C@@H](OC(=O)c2ccc(Br)cc2)C1(C)C</smiles>

\section{,}

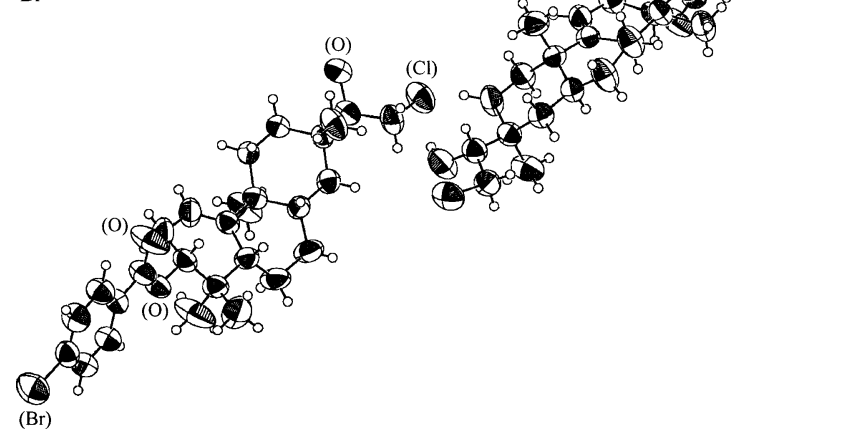

Fig. 5. The ORTEP Drawing of $\mathbf{1 6}$

Anisotropic ellipsoids are represented by a 50\% probability level.

NMR of authentic samples. The structure of 9 was also determined by comparison with those of reference spectral data. ${ }^{14)}$ The presence of compound 18 was confirmed as its acetate (10) isolated from the acetylated fraction of a mixture of compounds 9 and 18. Almost at the same time, Perry et al. reported the same compounds $\mathbf{9}$ and $\mathbf{1 8}$ from the same liverwort collected in a different location in New Zealand independently, and named glaucescens bisbibenzyl (GBB) A (9) and $\mathrm{B}(\mathbf{1 8}){ }^{14)}$

Heteroscyphus species produce calamenene- and 2,3secoaromadendrane-type sesquiterpenoids, or clerodane- and neoverrucosane-type diterpenoids. The present $H$. billardierii elaborates a clerodane-type diterpenoid; however, calamenene- and 2,3-secoaromadendrane-type sesquiterpenoids could not be identified in the present species.

The number of species assigned to the genus Plagiochila is more than 1600 . Of these, about 60 species have been investigated chemically and classified into five main chemotypes: i) 2,3-secoaromadendrane-type, ii) other sesquiterpenoid-type, iii) bibenzyl-type, iv) sesquiterpene lactonetype, and v) cyclic bisbibenzyl-type. ${ }^{2}$ Reporting on the isolation of diterpenoids from Plagiochila species is rare. ${ }^{1,2)}$ The present $P$. deltoidea produces ent-rosane- and ent-pimaranetype diterpenoids as main components. This is the first report of the isolation of ent-rosane- and ent-pimarane-type diterpenoids from Plagiochila species. Acetophenone derivatives are also rare secondary metabolites of liverworts. ${ }^{1,2)}$ The present $P$. fasciculata produces two acetophenones, $\mathbf{7}$ and $\mathbf{8}$, as main components. Thus, $P$. deltoidea and $P$. fasciculata are classified into different chemo-types in the Plagiochila species.

\section{Experimental}

Optical rotations were measured on a Jasco DIP-1000 polarimeter. IR spectra were recorded on a Jasco FT/IR-5300 infrared spectrophotometer. UV spectra were recorded on a Shimadzu UV-1650PC UV-visible spectrophotometer. CD spectra were recoded on a Jasco J-725 spectropolarimeter. The ${ }^{1} \mathrm{H}$ - and ${ }^{13} \mathrm{C}$-NMR spectra were measured on Varian Unity-600 $\left({ }^{1} \mathrm{H}\right.$; $600 \mathrm{MHz},{ }^{13} \mathrm{C}$; $\left.150 \mathrm{MHz}\right)$ and JEOL Eclipse-400 $\left({ }^{1} \mathrm{H} ; 400 \mathrm{MHz},{ }^{13} \mathrm{C}\right.$; $100 \mathrm{MHz})$ instruments. Chemical shift values are expressed in $\delta(\mathrm{ppm})$ downfield from tetramethylsilane as an internal standard ( $\left.{ }^{1} \mathrm{H}-\mathrm{NMR}\right)$, and in $\delta 77.03(\mathrm{ppm})$ from $\mathrm{CDCl}_{3}$ as a standard $\left({ }^{13} \mathrm{C}\right.$-NMR). Mass spectra were ob- tained on a JEOL JMS AX-500 instrument. X-Ray crystallographic analysis was carried out on a Mac Science DIP-2020 instrument. TLC was carried out using Silica gel $60 \mathrm{~F}_{254}$ plates (Merck). Column chromatography was performed on Silica-gel 60 (Merck, 230 - 400 and 35-70 mesh) and Sephadex LH-20 (Amersham Pharmacia Biotech, sol. $\mathrm{CH}_{2} \mathrm{Cl}_{2}-\mathrm{MeOH} 1: 1$ ). TLC plates were examined under UV $(254 \mathrm{~nm})$ light, and by spraying with $30 \%$ $\mathrm{H}_{2} \mathrm{SO}_{4}$ or Godin reagent, ${ }^{15)}$ followed by heating.

Plant Material Schistochila glaucescens (Ноок.) SтеPн. (NZ-109), Plagiochila deltoidea LINDENB. (NZ-128), Plagiochila fasciculata LindenB. (NZ-134), and Heteroscyphus billardieri (SchwaEgr.) SCHNiffn. (NZ-127), were collected from Sewell Peak, Ohakune, Te Aroha and Haast in New Zealand, 2000, respectively, and identified by J. E. Braggins (The University of Auckland). Their voucher specimens were deposited at the Faculty of Pharmaceutical Sciences, Tokushima Bunri University.

Extraction and Isolation The ether extract $(148 \mathrm{mg})$ of $H$. billardieri was divided into nine fractions by column chromatography (CC) on silica gel using an $n$-hexane-EtOAc gradient solvent system. 6 $\alpha$-Hydroxy3,12E,14-clerodatriene $(\mathbf{1}, 2 \mathrm{mg})$ was isolated from Fr. 2 by preparative TLC $(n$-hexane-EtOAc $4: 1)$.

$6 \alpha$-Hydroxy-3,12E,14-clerodatriene (1): $[\alpha]_{\mathrm{D}}^{20}-40.9^{\circ}\left(c=0.13, \mathrm{CHCl}_{3}\right)$. FT-IR $\mathrm{cm}^{-1}: 3440$. UV $\lambda_{\text {max }}(\mathrm{MeOH}) \mathrm{nm}(\log \varepsilon): 232(3.87) .{ }^{1} \mathrm{H}-$ and ${ }^{13} \mathrm{C}-$ NMR: Tables 1 and 2. HR-EI-MS $m / z$ : 288.2455 (Calcd for $\mathrm{C}_{20} \mathrm{H}_{32} \mathrm{O}$ : 288.2454). EI-MS $m / z$ (int.): $288\left[\right.$ [M] $^{+}$(1), 207 (46), 189 (100), 149 (9), 135 (64), 119 (17), 109 (41), 95 (57), 81 (67), 69 (11), 57 (13), 55 (13).

The ether extract $(611 \mathrm{mg})$ of $P$. deltoidea was divided into six fractions by column chromatography (CC) on silica gel using an $n$-hexane-EtOAc gradient solvent system. Fr. 3 was rechromatographed on silica gel and preparative HPLC (CHEMCOSORB $5 \mathrm{Si}-\mathrm{U}, n$-hexane-EtOAc $9: 1$ ) to afford (3R)-ent-1(10),15-rosadien-3-ol (2, $20.7 \mathrm{mg})$. (3R,15R)-ent-15,16-Epoxy1(10)-rosen-3-ol (3,37.8 mg) and acanthoic acid $(4,10.3 \mathrm{mg})$ were isolated from fr. 4 by Sephadex LH-20, silica gel and finally preparative HPLC (CHEMCOSORB 5Si-U, $n$-hexane-EtOAc 17:3). Fr. 5 was chromatographed on Sephadex LH-20 and silica gel to give five fractions. The third fraction, which was esterified with trimethylsilyldiazomethane, followed by preparative HPLC (CHEMCOSORB 5Si-U, $n$-hexane-EtOAc 17:3) gave methyl betulinate $(\mathbf{5}, 5.6 \mathrm{mg})$.

(3R)-ent-1(10),15-Rosadien-3-ol (2): $[\alpha]_{\mathrm{D}}^{20}+3.9^{\circ}\left(c=1.91, \mathrm{CHCl}_{3}\right)$. FTIR $\mathrm{cm}^{-1}$ : 3390. ${ }^{1} \mathrm{H}-$ and ${ }^{13} \mathrm{C}-\mathrm{NMR}$ : Tables 1 and 2 . HR-EI-MS $\mathrm{m} / \mathrm{z}$ : 288.2455 (Calcd for $\mathrm{C}_{20} \mathrm{H}_{32} \mathrm{O}: 288.2454$ ). EI-MS $\mathrm{m} / z$ (int.): $288[\mathrm{M}]^{+}$(49), 273 (62), 270 (99), 255 (100), 216 (64), 201 (56), 187 (23), 173 (20), 159 (22), 145 (24), 138 (82), 135 (37), 133 (40), 121 (32), 119 (34), 109 (33), $105(50), 93$ (40), 81 (44), 80 (33), 67 (21), 55 (25), 41 (21).

$(3 R, 15 R)$-ent-15,16-Epoxy-1(10)-rosen-3-ol $(3):[\alpha]_{\mathrm{D}}^{20}-4.9^{\circ} \quad(c=0.78$, $\mathrm{CHCl}_{3}$ ). FT-IR cm ${ }^{-1}: 3436 .{ }^{1} \mathrm{H}$ - and ${ }^{13} \mathrm{C}-\mathrm{NMR}$ : Tables 1 and 2. HR-EI-MS $m / z: 304.2404$ (Calcd for $\mathrm{C}_{20} \mathrm{H}_{32} \mathrm{O}_{2}: 304.2402$ ). EI-MS $m / z$ (int.): $304[\mathrm{M}]^{+}$ (45), 286 (100), 271 (94), 232 (44), 201 (24), 173 (22), 159 (20), 145 (23), 138 (49), 133 (32), 119 (31), 105 (38), 93 (29), 81 (19), 79 (17), 67 (12), 55 (15), 41 (13).

The ether extract $(535 \mathrm{mg})$ of $P$. fasciculata was divided into eight fractions by column chromatography (CC) on silica gel using an $n$-hexaneEtOAc gradient solvent system. Fr. 5 was subjected to Sephadex LH-20 CC to yield 2-Hydroxy-3,4,6-trimethoxy acetophenone $(7,58.3 \mathrm{mg})$ and a mixture of sesquiterpenoid fractions. The mixture of sesquiterpenoid fractions was subjected to preparative HPLC (CHEMCOSORB 5-ODS- $\mathrm{H}, \mathrm{CH}_{3} \mathrm{CN}$ ) to give ent-spathulenol $(6,4.2 \mathrm{mg})$. Fr. 7 was applied to Sephadex LH-20 and silica gel CC ( $n$-hexane-EtOAc $4: 1)$ to yield 2-hydroxy-4,6-dimethoxy acetophenone $(\mathbf{8}, 28.8 \mathrm{mg})$.

The ether extract $(874 \mathrm{mg})$ of $S$. glaucescens was divided into seven fractions by $\mathrm{CC}$ on silica gel using an $n$-hexane-EtOAc gradient solvent system. Fr. 3 was chromatographed on Sephadex LH-20, silica gel and preparative HPLC (CHEMCOSORB 5-ODS-H, MeOH) to afford GBB A $(\mathbf{9}, 4.2 \mathrm{mg})$, stigmasterol $(3.7 \mathrm{mg})$, and a mixture of GBB A (9) and B (18) fraction. The mixture of compounds $\mathbf{9}$ and $\mathbf{1 8}$ was acetylated with pyridine $(2 \mathrm{ml})$ and acetic anhydride $(2 \mathrm{ml})$, followed by purification by preparative HPLC (CHEMCOSORB 5-ODS-H, MeOH) after the solvents were removed, to yield GBB A acetate $(\mathbf{1 9}, 4.9 \mathrm{mg})$ and $\mathrm{GBB} B$ acetate $(\mathbf{1 0}, 10 \mathrm{mg})$. Marchantin $\mathrm{C}(\mathbf{1 1}, 4.6 \mathrm{mg})$ and neomarchantin $\mathrm{A}(\mathbf{1 2}, 11.5 \mathrm{mg})$ were isolated from fr. 4 by CC on Sephadex LH-20, silica gel and prep. HPLC (CHEMCOSORB 5 Si-U, $n$-hexane-EtOAc $17: 3)$.

GBB A acetate (19) $[\alpha]_{\mathrm{D}}^{19}-100.6^{\circ}\left(c=0.49, \mathrm{CHCl}_{3}\right)$. FT-IR cm ${ }^{-1}: 1766$, 1263. UV $\lambda_{\max }$ (EtOH) $\mathrm{nm}(\log \varepsilon): 272$ (3.84), 279 (3.79). ${ }^{1} \mathrm{H}-\mathrm{NMR}$ $\left(600 \mathrm{MHz}, \mathrm{CDCl}_{3}\right): \delta 6.93(2 \mathrm{H}, \mathrm{d}, J=8.5 \mathrm{~Hz}, \mathrm{H}-2$ and $\mathrm{H}-6), 7.11(2 \mathrm{H}, \mathrm{d}$, $J=8.5 \mathrm{~Hz}, \mathrm{H}-3$ and H-5), $3.06(1 \mathrm{H}, \mathrm{m}, \mathrm{H}-7), 3.11(1 \mathrm{H}, \mathrm{m}, \mathrm{H}-7), 2.90(1 \mathrm{H}$, $\mathrm{m}, \mathrm{H}-8), 3.16(1 \mathrm{H}, \mathrm{m}, \mathrm{H}-8), 6.51(1 \mathrm{H}, \mathrm{d}, J=8.5 \mathrm{~Hz}, \mathrm{H}-13), 6.55(1 \mathrm{H}, \mathrm{d}$, 
$J=8.5 \mathrm{~Hz}, \mathrm{H}-14), 6.29\left(1 \mathrm{H}, \mathrm{d}, J=1.9 \mathrm{~Hz}, \mathrm{H}-3^{\prime}\right), 6.78(1 \mathrm{H}, \mathrm{d}, J=7.4 \mathrm{~Hz}, \mathrm{H}-$ $\left.5^{\prime}\right), 6.97\left(1 \mathrm{H}, \mathrm{d}, J=8.2 \mathrm{~Hz}, \mathrm{H}-6^{\prime}\right), 2.46-2.51\left(2 \mathrm{H}, \mathrm{m}, \mathrm{H}-7^{\prime}\right.$ and $\left.\mathrm{H}-8^{\prime}\right)$, $2.54-2.61\left(2 \mathrm{H}, \mathrm{m}, \mathrm{H}-7^{\prime}\right.$ and $\left.\mathrm{H}-8^{\prime}\right), 6.18\left(1 \mathrm{H}, \mathrm{dd}, J=2.5,1.6 \mathrm{~Hz}, \mathrm{H}-10^{\prime}\right)$, $7.05\left(1 \mathrm{H}\right.$, ddd, $\left.J=8.2,2.7,0.8 \mathrm{~Hz}, \mathrm{H}-12^{\prime}\right), 7.21\left(1 \mathrm{H}, \mathrm{t}, J=8.2 \mathrm{~Hz}, \mathrm{H}-13^{\prime}\right)$, $6.77\left(1 \mathrm{H}, \mathrm{dd}, J=8.2,1.9 \mathrm{~Hz}, \mathrm{H}-14^{\prime}\right), 1.20\left(1 \mathrm{H}, \mathrm{m}, \mathrm{H}-1^{\prime \prime} \alpha\right), 1.61(1 \mathrm{H}, \mathrm{br}$, $\left.J=17.0 \mathrm{~Hz}, \mathrm{H}-1^{\prime \prime} \beta\right), 1.44\left(1 \mathrm{H}, \mathrm{m}, \mathrm{H}-2^{\prime \prime} \alpha\right), 1.55\left(1 \mathrm{H}, \mathrm{m}, \mathrm{H}-2^{\prime \prime} \beta\right), 1.16(1 \mathrm{H}, \mathrm{m}$, H-3" $\alpha), 1.42\left(1 \mathrm{H}, \mathrm{m}, \mathrm{H}-3^{\prime \prime} \beta\right), 1.25\left(1 \mathrm{H}, \mathrm{dd}, J=12.1,4.9 \mathrm{~Hz}, \mathrm{H}-5^{\prime \prime}\right), 2.11(1 \mathrm{H}$, dd, $\left.J=17.3,4.4 \mathrm{~Hz}, \mathrm{H}-6^{\prime \prime} \alpha\right), 1.81\left(1 \mathrm{H}, \mathrm{m}, \mathrm{H}-6^{\prime \prime} \beta\right), 1.90(1 \mathrm{H}, \mathrm{br}$ d, $J=15.7 \mathrm{~Hz}$, $\left.\mathrm{H}-9^{\prime \prime} \alpha\right), 1.82\left(1 \mathrm{H}, \mathrm{d}, J=15.7 \mathrm{~Hz}, \mathrm{H}-9^{\prime \prime} \beta\right), 5.20(1 \mathrm{H}, \mathrm{dd}, J=6.6,2.5 \mathrm{~Hz}, \mathrm{H}-$ $\left.11^{\prime \prime}\right), 6.06\left(1 \mathrm{H}, \mathrm{d}, J=6.6 \mathrm{~Hz}, \mathrm{H}-12^{\prime \prime}\right), 0.87\left(3 \mathrm{H}, \mathrm{s}, \mathrm{H}-13^{\prime \prime}\right), 0.84(3 \mathrm{H}, \mathrm{s}, \mathrm{H}-$ $\left.14^{\prime \prime}\right), 0.74\left(3 \mathrm{H}, \mathrm{s}, \mathrm{H}-15^{\prime \prime}\right), 2.32\left(3 \mathrm{H}, \mathrm{s}, \mathrm{OCOCH}_{3}\right) .{ }^{13} \mathrm{C}-\mathrm{NMR}$ : Table 3. HREI-MS $m / z: 698.3238$ (Calcd for $\mathrm{C}_{45} \mathrm{H}_{46} \mathrm{O}_{7}: 698.3244$ ). EI-MS $m / z$ (rel. int.): $698\left(\mathrm{M}^{+}, 49\right), 656(5), 628(1), 532(2), 482$ (11), 440 (34), $410(5), 303$ (8), 275 (3), 218 (27), 213 (22), 133 (3), 123 (9), 94 (100), 77 (7), 69 (4), 43 (9).

GBB B acetate $(10)[\alpha]_{\mathrm{D}}^{19}+69.1^{\circ}\left(c=1.00, \mathrm{CHCl}_{3}\right)$. FT-IR cm ${ }^{-1}: 1767$, 1275,1262 . UV $\lambda_{\max }(\mathrm{EtOH}) \mathrm{nm}(\log \varepsilon): 273$ (3.87), 281 (3.83). ${ }^{1} \mathrm{H}-\mathrm{NMR}$ $\left(600 \mathrm{MHz}, \mathrm{CDCl}_{3}\right): \delta 6.93(2 \mathrm{H}, \mathrm{d}, J=8.2 \mathrm{~Hz}, \mathrm{H}-2$ and $\mathrm{H}-6), 7.18(2 \mathrm{H}, \mathrm{d}$, $J=8.2 \mathrm{~Hz}, \mathrm{H}-3$ and $\mathrm{H}-5), 3.12(1 \mathrm{H}, \mathrm{dt}, J=14.3,4.9 \mathrm{~Hz}, \mathrm{H}-7), 3.21(1 \mathrm{H}, \mathrm{ddd}$, $J=14.3,11.5,4.4 \mathrm{~Hz}, \mathrm{H}-7), 2.84(1 \mathrm{H}, \mathrm{m}, \mathrm{H}-8), 3.33(1 \mathrm{H}, \mathrm{br}, \mathrm{H}-8), 6.51$ $(1 \mathrm{H}, \mathrm{d}, J=8.5 \mathrm{~Hz}, \mathrm{H}-13), 6.41(1 \mathrm{H}, \mathrm{d}, J=8.5 \mathrm{~Hz}, \mathrm{H}-14), 6.34(1 \mathrm{H}, \mathrm{d}$, $\left.J=1.9 \mathrm{~Hz}, \mathrm{H}-3^{\prime}\right), 6.80\left(1 \mathrm{H}, \mathrm{d}, J=8.0 \mathrm{~Hz}, \mathrm{H}-5^{\prime}\right), 6.97(1 \mathrm{H}, \mathrm{d}, J=8.0 \mathrm{~Hz}, \mathrm{H}-$ $\left.6^{\prime}\right), 2.27-2.34\left(2 \mathrm{H}, \mathrm{m}, \mathrm{H}-7^{\prime}\right.$ and $\left.\mathrm{H}-8^{\prime}\right), 2.73-2.82\left(2 \mathrm{H}, \mathrm{m}, \mathrm{H}-\mathrm{7}^{\prime}\right.$ and $\left.\mathrm{H}-8^{\prime}\right)$, $6.12\left(1 \mathrm{H}, \mathrm{dd}, J=2.5,1.9 \mathrm{~Hz}, \mathrm{H}-10^{\prime}\right), 7.03(1 \mathrm{H}, \mathrm{ddd}, J=8.2,2.5,0.8 \mathrm{~Hz}, \mathrm{H}-$ $\left.12^{\prime}\right), 7.22\left(1 \mathrm{H}, \mathrm{t}, J=8.2 \mathrm{~Hz}, \mathrm{H}-13^{\prime}\right), 6.79\left(1 \mathrm{H}, \mathrm{dd}, J=8.2,1.9 \mathrm{~Hz}, \mathrm{H}-14^{\prime}\right)$, $1.25-1.31\left(3 \mathrm{H}, \mathrm{m}, \mathrm{H}-1^{\prime \prime} \alpha, \mathrm{H}-2^{\prime \prime} \beta\right.$ and $\left.\mathrm{H}-3^{\prime \prime} \alpha\right), 0.60\left(1 \mathrm{H}, \mathrm{m}, \mathrm{H}-1^{\prime \prime} \beta\right), 1.42$ $\left(1 \mathrm{H}, \mathrm{m}, \mathrm{H}-2^{\prime \prime} \alpha\right), 0.91\left(1 \mathrm{H}, \mathrm{m}, \mathrm{H}-3^{\prime \prime} \beta\right), 0.96\left(1 \mathrm{H}, \mathrm{dd}, J=12.1,4.9 \mathrm{~Hz}, \mathrm{H}-5^{\prime \prime}\right)$, $1.84\left(1 \mathrm{H}\right.$, brt, $\left.J=14.6 \mathrm{~Hz}, \mathrm{H}-6^{\prime \prime} \alpha\right), 2.15\left(1 \mathrm{H}, \mathrm{dd}, J=17.3,3.3 \mathrm{~Hz}, \mathrm{H}-6^{\prime \prime} \beta\right)$, $1.39\left(1 \mathrm{H}, \mathrm{d}, J=15.9 \mathrm{~Hz}, \mathrm{H}-9^{\prime \prime} \alpha\right), 1.08\left(1 \mathrm{H}, \mathrm{brd}, J=15.9 \mathrm{~Hz}, \mathrm{H}-9^{\prime \prime} \beta\right), 5.32$ $\left(1 \mathrm{H}, \mathrm{dd}, J=7.4,2.7 \mathrm{~Hz}, \mathrm{H}-11^{\prime \prime}\right), 6.28\left(1 \mathrm{H}, \mathrm{d}, J=7.4 \mathrm{~Hz}, \mathrm{H}-12^{\prime \prime}\right), 0.73(3 \mathrm{H}, \mathrm{s}$, H-13"), 0.59 (3H, s, H-14"), 0.78 (3H, s, H-15"), $2.31\left(3 \mathrm{H}, \mathrm{s}, \mathrm{OCOCH}_{3}\right)$. ${ }^{13}$ C-NMR: Table 3. HR-EI-MS $m / z$ : 698.3243 (Calcd for $\mathrm{C}_{45} \mathrm{H}_{46} \mathrm{O}_{7}$ : 698.3244). EI-MS $m / z$ (rel. int.): $698\left(\mathrm{M}^{+}, 100\right), 656$ (9), 532 (2), 482 (5), 440 (15), 410 (4), 328 (8), 303 (7), 218 (24), 213 (14), 147 (3), 123 (8), 109 (8), 94 (57), 69 (4), 43 (4).

$\boldsymbol{m}$-Bromobenzoylation of 2 To a solution of compound $\mathbf{2}(8 \mathrm{mg})$ in dry $\mathrm{CH}_{2} \mathrm{Cl}_{2}(5 \mathrm{ml}), m$-bromobenzoic acid $(48 \mathrm{mg}), 1,3$-dicyclohexylcarbodiimide (DCC, $52 \mathrm{mg}$ ), and 4-dimethylaminopyridine (DMAP, $24 \mathrm{mg}$ ) were added and kept at room temperature overnight, then purified by CC on silica gel $(n-$ hexane-EtOAc $1: 1)$ to afford $m$-bromobenzoate $\mathbf{1 4}(12.5 \mathrm{mg})$.

$m$-Bromobenzoate 14: ${ }^{1} \mathrm{H}-\mathrm{NMR}\left(400 \mathrm{MHz}, \mathrm{CDCl}_{3}\right): \delta 0.89(3 \mathrm{H}, \mathrm{s}), 0.94$ $(3 \mathrm{H}, \mathrm{s}), 0.99(3 \mathrm{H}, \mathrm{s}), 1.00(3 \mathrm{H}, \mathrm{s}), 2.11(1 \mathrm{H}, \mathrm{m}), 2.33(1 \mathrm{H}, \mathrm{br} \mathrm{d}), 2.46(1 \mathrm{H}$, dddd $J=16.8,5.9,5.9,2.2 \mathrm{~Hz}), 4.85(1 \mathrm{H}, \mathrm{dd}, J=10.6,1.1 \mathrm{~Hz}), 4.93(1 \mathrm{H}, \mathrm{dd}$, $J=17.6,1.1 \mathrm{~Hz}), 5.00(1 \mathrm{H}, \mathrm{dd}, J=10.6,6.2 \mathrm{~Hz}), 5.43(1 \mathrm{H}, \mathrm{t}, J=2.6 \mathrm{~Hz}), 5.82$ $(1 \mathrm{H}, \mathrm{dd}, J=17.6,11.0 \mathrm{~Hz}), 7.33(1 \mathrm{H}, \mathrm{t}, J=7.7 \mathrm{~Hz}), 7.69(1 \mathrm{H}, \mathrm{d}, J=8.1 \mathrm{~Hz})$, $7.99(1 \mathrm{H}, \mathrm{d}, J=8.1 \mathrm{~Hz}), 8.17(1 \mathrm{H}, \mathrm{t}, J=1.8 \mathrm{~Hz}, \mathrm{H}-11)$. FAB-MS $(m-\mathrm{NBA})$ $m / z: \quad 495 \quad[\mathrm{M}+2+\mathrm{Na}]^{+}, \quad 493 \quad[\mathrm{M}+\mathrm{Na}]^{+} ; \quad(m-\mathrm{NBA}+\mathrm{KCl}) \quad m / z \quad 511$ $[\mathrm{M}+2+\mathrm{K}]^{+}, 509[\mathrm{M}+\mathrm{K}]^{+}$. EI-MS $m / z$ (int.): 270 (100), 255 (35), 199 (5), 185 (25), 134 (17), 120 (78), 108 (54), 81 (17), 55 (9), 41 (6). Crystal data: $\mathrm{C}_{27} \mathrm{H}_{35} \mathrm{BrO}_{2}, \quad \mathrm{Mr}=471.484$, Orthorhombic, $P 2_{1} 2_{1} 2_{1}, \quad a=6.3190(3) \AA$, $b=11.3430(8) \AA, c=33.884(3) \AA, \alpha=90.00^{\circ}, \quad \beta=90.00^{\circ}, \gamma=90.00^{\circ}, V=$ $2428.7(3) \AA^{3}$, Mo $K \alpha$ radiation, $\lambda=0.71073$, DIP Image plate, refinement on $F^{2}$, full matrix least squares refinement, $R(\mathrm{gt})=0.041$, $\mathrm{w} R(\mathrm{gt})=0.074$, $S(\mathrm{gt})=0.937,2111$ reflections, 272 parameters, only coordinates of $\mathrm{H}$ atoms refined, calculated weights sigma, cell refinement: Scalepack (HKL), data reduction: maXus, program used to refine structure: maXus.

Oxidation of 3 To a suspension of compound $3(6.5 \mathrm{mg})$ in $\mathrm{CH}_{2} \mathrm{Cl}_{2}$ $(2 \mathrm{ml})$ was added pyridinium chlorochromate (PCC, $8 \mathrm{mg}$ ), and the mixture was stirred for $1.5 \mathrm{~h}$ at room temperature. The reaction residue was chromatographed on silica gel ( $n$-hexane-EtOAc $4: 1)$ to give a ketone 15 $(5.7 \mathrm{mg})$.

15,16-Epoxy-ent-1(10)-rosen-3-one (15): $[\alpha]_{\mathrm{D}}^{19}+6.7^{\circ}\left(c=0.12, \mathrm{CHCl}_{3}\right)$. FT-IR cm ${ }^{-1}:$ 1714. CD (EtOH): $\Delta \varepsilon_{295 \mathrm{~nm}}-0.68, \Delta \varepsilon_{221 \mathrm{~nm}}-0.53 .{ }^{1} \mathrm{H}-\mathrm{NMR}$ $\left(600 \mathrm{MHz}, \mathrm{CDCl}_{3}\right): \delta 0.88(3 \mathrm{H}, \mathrm{s}, \mathrm{H}-17), 1.00(3 \mathrm{H}, \mathrm{s}, \mathrm{H}-20), 1.03(3 \mathrm{H}, \mathrm{s}, \mathrm{H}-$ 19), $1.07(3 \mathrm{H}, \mathrm{s}, \mathrm{H}-18), 1.12(1 \mathrm{H}, \mathrm{m}, \mathrm{H}-14 \beta), 1.15(1 \mathrm{H}, \mathrm{m}, \mathrm{H}-12 \beta), 1.29$ $(1 \mathrm{H}, \mathrm{m}, \mathrm{H}-14 \alpha), 1.32(1 \mathrm{H}, \mathrm{m}, \mathrm{H}-7), 1.41-1.47(2 \mathrm{H}, \mathrm{m}, \mathrm{H}-11 \beta, \mathrm{H}-12 \alpha)$,
$1.59-1.68(4 \mathrm{H}, \mathrm{m}, \mathrm{H}-6, \mathrm{H}-6, \mathrm{H}-7, \mathrm{H}-8), 1.73(1 \mathrm{H}, \mathrm{m}, \mathrm{H}-11 \alpha), 2.48(1 \mathrm{H}$, br d, $J=12.9 \mathrm{~Hz}, \mathrm{H}-5), 2.64(1 \mathrm{H}, \mathrm{t}, J=4.7 \mathrm{~Hz}, \mathrm{H}-16), 2.66(1 \mathrm{H}, \mathrm{dd}, J=4.7$, $3.0 \mathrm{~Hz}, \mathrm{H}-16), 2.71(1 \mathrm{H}, \mathrm{dd}, J=3.8,3.0 \mathrm{~Hz}, \mathrm{H}-15), 2.75(1 \mathrm{H}$, ddd, $J=21.2$, $3.8,2.7 \mathrm{~Hz}, \mathrm{H}-2 \beta), 3.07(1 \mathrm{H}, \mathrm{dt}, J=21.2,3.3 \mathrm{~Hz}, \mathrm{H}-2 \alpha), 5.52(1 \mathrm{H}, \mathrm{q}$, $J=3.6 \mathrm{~Hz}, \mathrm{H}-1$ ) ${ }^{13} \mathrm{C}-\mathrm{NMR}$ : Table 2. HR-EI-MS $m / z$ : 302.2245 (Calcd for $\mathrm{C}_{20} \mathrm{H}_{30} \mathrm{O}_{2}: 302.2246$ ). EI-MS $m / z$ (int.): $302[\mathrm{M}]^{+}$(100), 287 (51), 232 (16), 217 (12), 201 (19), 173 (21), 159 (17), 136 (80), 119 (28), 107 (30), 93 (35), 77 (27), 55 (16), 41 (17).

p-Bromobenzoylation of 3 To a solution of compound $3(14.5 \mathrm{mg})$ in $\mathrm{CH}_{2} \mathrm{Cl}_{2}(2 \mathrm{ml})$ and pyridine $(1 \mathrm{ml}), p$-bromobenzoic acid $(16 \mathrm{mg})$ and DMAP $(3 \mathrm{mg}$ ) were added and kept at room temperature for $2 \mathrm{~d}$, then purified by $\mathrm{CC}$ on silica gel ( $n$-hexane-EtOAc $4: 1$ ) to afford $p$-bromobenzoate $\mathbf{1 6}$ (14.3 mg).

$p$-Bromobenzoate 16: ${ }^{1} \mathrm{H}-\mathrm{NMR}\left(400 \mathrm{MHz}, \mathrm{CDCl}_{3}\right): \delta 0.88(3 \mathrm{H}, \mathrm{s}), 0.93$ $(3 \mathrm{H}, \mathrm{s}), 0.94(3 \mathrm{H}, \mathrm{s}), 0.97(3 \mathrm{H}, \mathrm{s}), 2.10(1 \mathrm{H}, \mathrm{m}), 2.31(2 \mathrm{H}, \mathrm{d}, J=2.9 \mathrm{~Hz})$, $2.46(1 \mathrm{H}, \mathrm{m}), 3.40(1 \mathrm{H}, \mathrm{brd}, J=10.6 \mathrm{~Hz}), 3.50(1 \mathrm{H}, \mathrm{t}, J=10.6 \mathrm{~Hz}), 3.80(1 \mathrm{H}$, dd, $J=11.0,1.8 \mathrm{~Hz}), 4.98(1 \mathrm{H}, \mathrm{dd}, J=10.6,6.2 \mathrm{~Hz}), 5.43(1 \mathrm{H}, \mathrm{m}), 7.58(2 \mathrm{H}$, d, $J=8.8 \mathrm{~Hz}), 7.91(2 \mathrm{H}, \mathrm{d}, J=8.8 \mathrm{~Hz})$. FAB-MS $(m-\mathrm{NBA}) \mathrm{m} / \mathrm{z}: 547$ $[\mathrm{M}+2+\mathrm{Na}]^{+}, 545[\mathrm{M}+\mathrm{Na}]^{+} ;(m-\mathrm{NBA}+\mathrm{KCl}) \mathrm{m} / z 563[\mathrm{M}+2+\mathrm{K}]^{+}, 561$ $[\mathrm{M}+\mathrm{K}]^{+}$. Crystal data: $\mathrm{C}_{27} \mathrm{H}_{36} \mathrm{BrClO}_{3}, \mathrm{Mr}=523.944$, Triclinic, $P_{1}$, $a=9.9650(5) \AA, \quad b=10.0940(6) \AA, \quad c=14.6560(13) \AA, \quad \alpha=94.54^{\circ}, \quad \beta=$ 94.953(2) $)^{\circ}, \gamma=114.927(3)^{\circ}, V=1321.0(2) \AA^{3}, \mathrm{MoK} \alpha$ radiation, $\lambda=0.71073$, DIP Image plate, Refinement on $F^{2}$, full matrix least squares refinement, $R(\mathrm{gt})=0.053, \mathrm{w} R(\mathrm{gt})=0.1379, S(\mathrm{ref})=1.073,7592$ reflections, 577 parameters, only coordinates of $\mathrm{H}$ atoms refined, calculated weights calc, cell refinement: Scalepack (HKL), data reduction: maXus, program used to solve structure: SHELXS-97, Program used to refine structure: SHELXS-97.

Acknowledgments We thank Dr. M. Tanaka (TBU) and Miss Y. Okamoto (TBU) for measurements of NMR and mass spectra. Thanks are also due to Prof. J. E. Braggins (The Auckland University) for the identification of the species. This work was supported by a Grant-in-Aid for Scientific Research (A) (No. 11309012) from the Ministry of Education, Culture, Sports, Science and Technology.

\section{References}

1) Asakawa Y., "Progress in the Chemistry of Organic Natural Products," Vol. 42, ed. by Herz W., Grisebach H., Kirby G. W., Springer Verlag, Vienna, 1982, pp. 1-285.

2) Asakawa Y., "Progress in the Chemistry of Organic Natural Products," Vol. 65, ed. by Herz W., Grisebach H., Kirby G. W., Moore R. E., Steglich W., Tamm Ch., Springer Verlag, Vienna, 1995, pp. 1-562.

3) Asakawa Y., Toyota M., Konrat M., Braggins J. E., Phytochemistry, 62, $439-452$ (2003).

4) Nagashima F., Kasai W., Kondoh M., Fujii M., Watanabe Y., Braggins J. E., Asakawa Y., Chem. Pharm. Bull., 51, 1189-1192 (2003).

5) Allison K. W., Child J., "The Liverworts of New Zealand," University of Otago Press, Dunedin, 1975, pp. 1-300.

6) Kim Y.-H., Chung B. S., Sankawa U., J. Nat. Prod., 51, 1080-1083 (1988).

7) Yagi A., Okamura N., Haraguchi Y., Noda K., Nishioka I., Chem. Pharm. Bull., 26, 1798-1802 (1978).

8) Asakawa Y., Toyota M., Takemoto T., Phytochemistry, 19, 21412145 (1980).

9) Takeda Y., Fatope M. O., J. Nat. Prod., 51, 725-729 (1988).

10) Brown G. D., J. Nat. Prod., 55, 1756-1760 (1992).

11) Lorimer S. D., Perry N. B., Planta Med., 60, 386-387 (1994)

12) Tori M., Masuya T., Asakawa Y., J. Chem. Res. S, 1990, 36-37 (1990).

13) Asakawa Y., Toyota M., Matsuda R., Takikawa K., Takemoto T., Phytochemistry, 22, 1413-1415 (1983).

14) Scher J. M., Burgess E. J., Lorimer S. D., Perry N. B., Tetrahedron, 58, 7875-7882 (2002).

15) Godin P., Nature (London), 174, 134 (1954). 